American University Washington College of Law

Digital Commons @ American University Washington College of

Law

Contributions to Books

Scholarship \& Research

2012

\title{
The Reform of the Governance of the IFIs: A Critical Assessment
}

Daniel Bradlow

American University Washington College of Law, ddbradlow@gmail.com

Follow this and additional works at: https://digitalcommons.wcl.american.edu/facsch_bk_contributions

Part of the Law Commons

\section{Recommended Citation}

Bradlow, Daniel, "The Reform of the Governance of the IFIs: A Critical Assessment" (2012). Contributions to Books. 68.

https://digitalcommons.wcl.american.edu/facsch_bk_contributions/68

This Book Chapter is brought to you for free and open access by the Scholarship \& Research at Digital Commons @ American University Washington College of Law. It has been accepted for inclusion in Contributions to Books by an authorized administrator of Digital Commons @ American University Washington College of Law. For more information, please contact kclay@wcl.american.edu. 


\section{PART I}

\section{LAW OF INTERNATIONAL Organizations: Issues Confronting IFIs}


Electronic copy available at: http://ssrn.com/abstract=1939786 


\section{The Reform of the Governance of the IFIs}

A Critical Assessment

Daniel D. Bradlow*

The first two global international financial institutions (IFIs), the International Monetary Fund (IMF) and the International Bank for Reconstruction and Development (IBRD), were created at the Bretton Woods Conference in 1944. Their governance, their functions, and, ultimately, their membership were shaped by the geopolitical realities of the time. ${ }^{1}$ The IMF's function was to use its financial resources to create and support a rules-based international monetary system based on stable exchange rates and relatively free payments for current transactions. ${ }^{2}$ The IMF was expected to use its surveillance authority to oversee the operation of the international monetary system and advise members on their balance of payments and the maintenance of the par value of their currencies. ${ }^{3}$ The founding states anticipated that the IMF would use its financial resources to help member states correct their balance-of-payments problems in ways that were not destructive to international or domestic prosperity. The Articles of Agreement of the IMF made clear that, although member states were surrendering some control over their exchange rates and their policy discretion in regard to current transactions, they retained full authority to regulate capital transfers as they saw fit. ${ }^{4}$ Thus, the founding member states did not anticipate that the IMF would play any direct role in the regulation or oversight of either national or international financial markets or in the international allocation of credit. At the time, this made good sense because very few banks operated across national boundaries, all financial regulation was national, and international financial activity was a relatively small part of the global financial scene.

* The views in this chapter are the author's own and should not be attributed to any institution with which he is affiliated. The author would like to thank Veronique Lendresse for her research assistance.

1 For a history of these institutions, see, for example, Devesh Kapur, John P. Lewis, \& Richard Webb, The World Bank: Its First Half Century (Brookings Institute 1997); Margaret Garritsen De Vries, The IMF in a Changing World, 1945-85 (Intl. Monetary Fund 1986).

2 Articles of Agreement of the IMF, Article I, available at <http:/ /www.imf.org/external/ pubs $/ \mathrm{ft} / \mathrm{aa} />$.

3 Under the system established with the creation of the IMF, each state was expected to establish the value of its currency in terms of the U.S. dollar, which would be fixed in terms of gold. The member state was expected to maintain this value, known as the "par value of the currency," within narrow limits. It could change the par value only with the consent of the IMF. 
The IBRD's role was to help finance the reconstruction of Europe and the economic development of its erstwhile colonies and a few independent states in Africa, Asia, and Latin America. ${ }^{5}$ At the time this was understood to mean that the IBRD would provide financial support primarily for physical infrastructure projects in member states that were not able to raise sufficient financing from private sources.

Since the IMF and the IBRD were established, the world has changed dramatically. The number of states participating in the global monetary and financial system has increased; the IMF and the institutions in the World Bank Group $^{6}$ each now have more than 180 member states. In addition, many more IFIs have been created. There are now IFIs such as the International Development Association (IDA), which provides concessional financing to the poorest states; regional and subregional development banks; and institutions dedicated to funding the private sector, such as the International Finance Corporation (IFC). The par value system of exchange rates has broken down; we now live in a world with freely fluctuating exchange rates and liberalized financial flows. In this environment, international financial flows exceed by several orders of magnitude annual international trade volumes; international capital markets are a key component of the global financial order; and, in a number of cases, the IFIs either compete or cooperate with the private sector and other official creditors in funding projects in their member states.

In addition, no financial regulator in a major economic power can effectively regulate its financial industry without addressing the international aspects of that industry's operations and without collaborating in some way with its counterparts in other key countries. As a result, the IMF has become involved in international financial market oversight and in reviewing its member states' financial regulatory frameworks. ${ }^{7}$ It is supported in these efforts by a broad range of relatively new international forums and bodies involved in the various aspects of international financial governance. These include the Financial Stability Board (FSB), the Basel Committee of Banking Supervision, the International Organization of Securities Commissions, and the International Association of Insurance Administrators. ${ }^{8}$ The IMF also plays a leading role when a member state needs support in dealing with its international debt problems.

IBRD Articles of Agreement, Article I, available at <http: / / go.worldbank.org/ OFICOZQLQ0.>

6 The members of the World Bank Group are the International Bank for Reconstruction and Development (IBRD), the International Development Association (IDA), the International Finance Corporation (IFC), the Multilateral Investment Guarantee Agency (MIGA), and the International Centre for the Settlement of Investment Disputes (ICSID).

7 The IMF's website provides a useful overview of the diversity of its activities; see $<$ http:/ / www.imf.org>.

8 For a useful overview of these institutions and their functions, see, generally, Howard Davies \& David Green, Global Financial Regulation: The Essential Guide (Polity Press 2008); Kern Alexander, Rahul Dhumale, \& John Eatwell, Global Governance of Financial Systems: The International Regulation of Systemic Risk (Oxford U. Press 2006). 
The various entities in the World Bank Group and the regional development banks are involved in helping their member states develop the institutional and technical capacity to effectively regulate, supervise, and manage their evolving financial systems and to develop capital markets. The growing complexity of the international financial and economic system and our deepening understanding of the complexities of poverty and development are also changing the ways in which these multilateral development banks (MDBs) operate. They can no longer limit their operations to funding physical infrastructure projects. They are now involved in helping their member states improve various aspects of their governance arrangements; deal with such complex social issues as legal and judicial reform, education reform, vulnerable population groups, and health care; confront such environment-related challenges as climate change, sustainable energy and water strategies, and food security; manage their public finances; and fund physical infrastructure projects. $^{9}$

These changes are occurring at the same time that the global political economy is undergoing a shift in power. This process of change is not yet over, and its final outcome is not yet clear. Currently, the rising powers are powerful enough to demand changes in some aspects of the existing international economic governance arrangements but not powerful enough to shape the global economic governance agenda, including reforming the key institutions in global financial governance. The existing powers, primarily the Group of Seven (G7) countries, still control the global agenda and can still block reform efforts that they oppose. This situation has two implications for governance reforms. First, it suggests that reform any faster or more extensive than the existing powers are willing to accept is not feasible in the short run. This situation may change over time as power shifts more toward newly rising powers, but at the moment, this is an important constraint on governance reform. Second, the current governance reforms are unlikely to produce sustainable and stable governance arrangements in the IFIs until the process of change in the balance of global power plays itself out.

One effect of these changes has been to produce differences in the relationships between the IFIs and their member states. Today, the major IFIs, de facto, are important actors in the policy-making processes of many of the member states that rely on their financial services. The IFIs have become more sensitive to the interests of those member states that use their financial services and are gaining international power and influence while remaining subject to the influence of the IFI's richer and more powerful member states.

As is clear from the number of financial crises that the world has experienced since the 1980s, international governance arrangements do not always

9 The websites of the MDBs provide a useful overview of the diversity of their activities. See, for example, World Bank Group, <http:/ / www.worldbank.org>; African Development Bank, $<$ http:/ / www.afdb.org>; Asian Development Bank, <http:/ / www.adb.org>; European Bank for Reconstruction and Development, <http:/ / www.ebrd.org>; Inter-American Development Bank, <http: / / www.iadb.org>; International Finance Corporation, <http:/ / www.ifc.org>. 
function effectively. In fact, even though some significant reforms in IFIs' governance occurred before then, the 1997 Asian financial crisis resulted in a general agreement that both the existing arrangements for international financial governance, often referred to as the global financial architecture, and the governance of the key IFIs needed to be reformed. However, since that time, the attention paid to this topic has been inversely proportional to the well-being of the global financial system. Consequently, during the early years of the millennium, the topic was not high on the international agenda and some commentators even began to question the need for the IFIs, particularly the IMF.

As signs that the global political economy could be running into problems appeared and accelerated after the financial crisis fully erupted in 2008, there were significant efforts to reform the governance of the IFIs. These efforts resulted in changes in voting arrangements, representation on boards of directors, and the selection of top management. ${ }^{10}$ These reforms were complemented by a strengthening of the role of some of the IFIs, most notably the IMF.

Given all the governance changes that the IFIs have undergone in recent years, now is an opportune time to assess the actual significance of these reforms. Such an evaluation asks three questions: What has been achieved in terms of reforming the governance of the IFIs? What standards should one use in assessing the adequacy of these reforms? How well do these reforms measure up to these assessment standards?

The thesis of this chapter is that, despite all the governance changes that the IFIs have undergone, they still do not have adequate governance arrangements and will need to undergo further reform if they are to perform their mandates effectively. In order to establish this thesis, this chapter is divided into four parts. First, it describes the reforms the IFIs have agreed to and have implemented. Second, it sets out some benchmarks against which these governance reforms can be measured. Third, it assesses the adequacy of the reforms undertaken based on the benchmarks identified in the second section. The final section is a conclusion.

\section{The Governance Reform of the IFIs}

Over the past twenty years, the IFIs, particularly the World Bank ${ }^{11}$ and the IMF, ${ }^{12}$ have undergone more substantial changes in their governance and

10 The recent election of another European, Christine Lagarde, as the management director of the IMF suggests that these reforms may not be as solid as they first appeared.

11 For a useful overview of the reforms at the World Bank Group, see <http:/ / www.worldbank .org $/ \mathrm{html} /$ extdr/worldbankreform/ >.

12 For a useful overview of the reforms at the IMF, see IMF Finance, Legal and Strategy, Policy and Review Departments, IMF Quota and Governance Reform-Elements of an Agreement (IMF, Oct. 31, 2010); IMF, Factsheet: A Changing IMF-Responding to the Crisis (Mar. 16, 2011), available at <http:/ / www.imf.org/external/np/ exr/facts/ changing.htm>. 
operational practices than have other international organizations. ${ }^{13}$ As a result, they are more transparent and more open to interactions with their external stakeholders than are other international organizations. The World Bank is also more accountable to its various stakeholders than are other international organizations.

\section{Voice and Vote}

One of the most persistent complaints about the governance of the IFIs, particularly the World Bank and the IMF, was that they were not representing their membership very effectively and they needed to realign both their voting arrangements and the way in which their member states were represented on their boards of executive directors. In the past few years, both the World Bank and the IMF have made efforts to address this issue. The IMF has increased its member states' basic votes in order to enhance the representation of its smallest and poorest member states in its total vote. It also increased and redistributed the quotas of some of its member states to ensure that formerly underrepresented states are now more appropriately represented in the total votes of the organization. As a result, a number of the major emerging markets now have some of the biggest quotas in the IMF. In addition, the IMF membership agreed to reassess the formula used in assigning quotas (and therefore votes) to its member states so that the counts more accurately reflect the role of its member states in the global financial and economic system. ${ }^{14}$

The membership of the IMF has also agreed to reform the structure of its board of executive directors. In particular, it has agreed to appoint a second alternative executive director to support those executive directors who represent large numbers of states. There will also be a reduction in the European representation on the board and a concomitant increase in the developingcountry representatives on the board. Finally, the membership has also agreed to move to an all-elected board, thereby eliminating the privileged position that its five largest shareholders held on the board. ${ }^{15}$

The World Bank has made similar reforms. Its member states have agreed to increase the share of its developing and transitional member states in its total vote. ${ }^{16}$ Following the implementation of these changes, these countries will constitute 47.19 percent of the total vote in the Bank. This represents an

13 It should be noted that the regional development banks have also undertaken substantial governance reforms. However, they tend to follow the lead of the World Bank in their reform efforts. Consequently, it can be assumed that these banks have implemented roughly analogous reforms to those that the World Bank has undertaken and described in this section.

14 For a general overview of these reforms, see IMF Press Release No. 08/64, IMF Executive Board Recommends Reforms to Overhaul Quota and Voice (Mar. 28, 2008), available at <http:/ / www.imf.org/ external/np/sec/pr/2008/pr0864.htm>.

15 Id.

16 For an overview of these voting reforms, see <http://web.worldbank.org/WBSITE/ EXTERNAL/NEWS/0,,contentMDK:22556192 menuPK:34457 pagePK:34370 piPK:34424 rheSitePK:4607,00.html>. 
increase of 4.59 percent in their share of the total vote since 2008. In addition, within these totals, there will be some realignment of voting shares so that the most dynamic emerging markets increase their share of the votes and have a vote in the Bank that is more commensurate with their role in the global economy. The member states have also increased the size of the Bank's Board from 24 to 35 members, with the new member being a third African executive director.

\section{Senior Management}

Historically, the selection of the chief executive officers of the IMF and the World Bank has been governed by a "gentlemen's agreement" according to which the managing director of the IMF was a European and the president of the World Bank was an American. In addition, the process through which this person was selected was opaque and closed to outside participation. The member states have now agreed that the process should be transparent and understandable to outsiders and that it should be based on merit without regard to national origin. ${ }^{17}$ Analogous procedures should also apply to the selection of other senior management officials. It is important to note that the IMF failed to fully implement this reform and followed the old "gentlemen's agreement" in its recent selection of a new managing director. Despite their commitments to the contrary, the leading member states banded together to elect another European as the IMF's managing director. ${ }^{18}$

\section{Accountability}

Over the past 20 years, the World Bank and the other MDBs have made significant efforts to become more accountable. In 1993, the World Bank created the Inspection Panel, the first mechanism in any international organization through which nonstate actors that believed that they had been harmed by the failure of the Bank to comply with its own policies and procedures could have their concerns investigated by an independent body that reports to the Board of the Bank. This was an important breakthrough for all international organizations; subsequently, most MDBs created similar mechanisms, known

17 See, for example, Development Committee, Strengthening Governance and Accountability: Shareholder Stewardship and Oversight, DC2011-0006 (Apr. 4, 2011) (discussing selection process for World Bank president), available at <http:/ / siteresources.worldbank.org/ DEVCOMMINT / Documentation/ 22885978/DC2011-0006\%28E\%29Governance.pdf>; G20, Declaration on Strengthening the Financial System (Apr. 2, 2009), available at $<\mathrm{http}: / /$ www .g20.org/Documents/Fin_Deps_Fin_Reg_Annex_020409_-_1615_final.pdf>; G20, Declaration Summit on Financial Markets and the World Economy (Nov. 15, 2008), available at $<$ https: / / www.g20.org/Documents/g20_summit_declaration.pdf > .

18 See "IMF Executive Board Selects Christine Lagarde as Managing Director," Press Release No. 11/ 259 (Jun. 28, 2011), available at: <http://www.imf.org/external/np/sec/pr/2011/ pr11259.htm>. 
collectively as independent accountability mechanisms. ${ }^{19}$ Interestingly, the one IFI that has not created such a mechanism is the IMF. ${ }^{20}$

The IFIs have taken other steps to improve their accountability to their member states and to the public, who ultimately provide their funding. Significantly, the World Bank has agreed that it will establish dual performance reviews of its president by its Board and of the Board by the president and senior management. The goal of these reviews will be to ensure more effective performance by both parties. The World Bank is also working to create a corporate governance scorecard that will allow for more effective assessment of its governance and the efficacy of its operations. ${ }^{21}$

\section{Transparency}

The most substantial and far-reaching change in the operations of the IFIs has been in regard to transparency. All the IFIs have adopted informationdisclosure policies. ${ }^{22}$ These policies, many of which have been revised over time, have steadily increased the amount of information that the IFIs disclose. As a result, they are rapidly establishing as a standard operating procedure that all their documents and information be publicly available unless specifically decreed not to be so. It is important to note that this does not mean that all information is disclosed. In a number of cases, the clients of the IFIs-either the member state or the private sector borrower-claim that the information belongs to them and cannot be disclosed due to market sensitivities.

\section{Operational Policies}

The MDBs have always had policies to guide their staff in the complex operations that they undertake. ${ }^{23}$ However, initially these policies were viewed as internal documents of no interest to anyone other than the staff. Over time, this perception changed, and the policies are now publicly available. One consequence of this development is that the policies, particularly those dealing with

19 For overviews of these various independent accountability mechanisms and comparisons of their structures and mandates, see Richard E. Bissell \& Suresh Nanwani, Multilateral Development Bank Accountability Mechanisms: Developments and Challenges, 6(1) Manchester J. Intl. Econ. L., 2 (2009); Daniel D. Bradlow, Private Complaints and International Organizations: A Comparative Study of the Independent Inspection Mechanisms in International Financial Institutions, 36 Geo. J. Intl. L. 403 (2005).

20 See Daniel D. Bradlow, Operational Policies and Procedures and an Ombudsman, in Accountability of the International Monetary Fund 88 (Barry Carin \& Angela Wood ed., Ashgate 2005).

21 See, for example, Development Committee, supra note 17, at 2 (discussing the creation of a corporate scorecard for the World Bank Group).

22 See, for example, IMF, FactSheet Transparency at the IMF (Mar. 24, 2011), available at <http:/ / www.imf.org/external/np/exr/facts/trans.htm>; World Bank Policy on Access to Information (Jul. 1, 2010), available at <http: / / www-wds.worldbank.org/ external / default / WDSContentServer/WDSP/IB/2010/06/03/000112742_20100603084843/Rendered/PDF / 548730Access0I1y0Statement01Final1.pdf $>$.

23 See, for example, the World Bank Operational Manual, available at $<$ http: / / web.worldbank .org / WBSITE/EXTERNAL / PROJECTS / EXTPOLICIES / EXTOPMANUAL / 0,menuPK:647 01637 pagePK:51628525 piPK:64857279 theSitePK:502184,00.html>. 
the controversial social and environmental aspects of the MDB operations, have become the subject of great public interest and public debate. These policies have also tended to be the ones most often invoked in the requests for inspection to the independent accountability mechanisms.

One consequence of this development is that the MDBs have recognized that their policies have significance and relevance outside the institutions and that their external stakeholders have the capacity to influence the content of these policies. As a result, the MDBs have begun to develop informal, transparent, and participatory procedures for making these policies. ${ }^{24}$ The World Bank Group, in particular, has used such informal procedures with sufficient frequency that it is developing an implicit rule-making procedure that involves disclosure of policy drafts, opportunities for public comment on these drafts, and explanations of how the public comments have been addressed by the institution in formulating the final versions of the policy.

Interestingly, the other IFIs have not followed this practice in a consistent way. Most of the regional MDBs have occasionally provided opportunities for public consultation on drafts of policies and practices, particularly in regard to the structuring or amending of their independent accountability mechanisms. However, they have not regularly done so in regard to their substantive operational policies. The IMF has not developed such an implicit policy, partly because it does not have a comparable set of publicly available operational policies. It does, however, have some policies that are publicly available and, in at least one case-its policy on conditionality-it followed a process similar to the evolving process in the World Bank: ${ }^{25}$ the policy was developed in a relatively transparent and participatory process.

\section{Principles for Assessing the Governance of the MDBs}

This section formulates five principles that can help assess the efficacy of the governance reforms undertaken by the IFIs: a holistic approach to development; flexible management; respect for applicable international law; coordinated specialization; and good administrative practice.

\section{Holistic Approach to Development}

The original vision of development as an economic process that focuses on growth, as measured by gross domestic product (GDP) per capita, is no longer seen as sufficient. It is now recognized that the development of individuals and societies is influenced by both noneconomic factors and economic criteria. ${ }^{26}$ This insight has led to a new understanding of development as a national Financial Institutions, in International Financial Institutions and International Law 199 (Daniel D. Bradlow \& David B. Hunter ed., Kluwer Law International 2010).

26 UNDP, Human Development Report 1990 (Oxford U. Press 1990); Amartya Sen, Development 
comprehensive and holistic process that involves intertwined economic, environmental, social, cultural, political, and even ethical dimensions. According to this view, the economic aspects of development and its social, political, environmental, and cultural aspects are all components of one dynamically integrated process. Thus, one measure of the performance of the IFIs should be the extent to which their own governance arrangements support their institutions' ability to implement this holistic vision of development.

\section{Flexible Management}

The principle of flexible management means that the governance and operations of the IFIs must be sufficiently flexible and dynamic that they can adapt to the differing and changing needs, circumstances, and activities of their diverse stakeholders. For example, the IFIs must have the ability to assist member states with the technical, institutional, and economic capacity to design, implement, and manage large, complex operations, often with substantial social, environmental, and cultural impacts and policy implications; to help countries with limited technical, institutional, and economic capacity undertake infrastructure projects and governance reform projects that are both commensurate with their management capacity and appropriately scaled to meet their needs; and to finance and support smaller-scale operations that are more focused on directly meeting the needs of the poor and other vulnerable population groups in their member states.

Two corollaries follow from the principle of flexible management. First, the IFIs themselves need to have personnel and the management systems that enable them to effectively respond to the broad range of needs of their member states; they need to ensure that their staff has both the social and the cultural background necessary to understand the people and countries in which they operate and the technical expertise and professional experience to meet the demands of their member states. In addition, the IFIs need to have effective feedback mechanisms so that they can understand all the impacts of their operations in their borrower countries. Without such capacity to learn lessons from their operations, the IFIs are unlikely to fully understand their successes and failures and are more likely to repeat the failures. In addition, they are less likely to be able to identify problems in their operations in a timely manner and to mitigate any unintended or unanticipated adverse consequences of these operations.

Second, given the broad range and diversity of the demands on IFI's services, no IFI can fully meet the needs of its member states. Consequently, the IMF, the World Bank, and the other MDBs need some mechanism for coordinating their operations and ensuring that together the organizations can effectively address their member states' demands. One possible approach for 
ensuring that overall these institutions function in a flexible, efficient, and not unduly centralized manner is based on the principle of subsidiarity, ${ }^{27}$ which holds that all decisions should be taken at the lowest level in the system compatible with effective decision making. This principle is complicated to implement because it must apply both in standard operating conditions and in crisis situations, which may require that decision-making authority be moved to a different level in the system or institution than is the case during standard operating conditions.

\section{Respect for Applicable International Law}

All the IFIs are formal international organizations created by treaties. Consequently, they are subjects of international law and should comply with applicable international legal principles. ${ }^{28}$ Although international law does not offer many detailed standards that the IFIs can apply to international financial transactions, it does provide general principles that they can use in structuring their governance arrangements. ${ }^{29}$ In particular, the IFIs' governance structures and decision-making principles should conform to universally applicable customary and treaty-based international legal principles. Four sets of principles are pertinent in this regard. ${ }^{30}$

\section{Sovereignty}

The first is the principle of respect for national sovereignty, which must be respected even though, by joining an IFI, a state agrees to surrender some decision-making autonomy in return for the benefits of participation in the IFI. This means that, even though their different power and wealth characteristics and the particular voting rules in the various IFIs mean, de facto, that the amount of independence the member states give up on joining the IFI will be related to their power and wealth and their need for the services of the particular IFI, all member states remain sovereign states with equal international

27 The principle of subsidiarity is defined in Article 5 of the treaty establishing the European Community. It is intended to ensure that decisions are made as closely as possible to the citizen and that constant checks are made as to whether action at the community level is justified in light of the possibilities available at the national, regional, or local level. Specifically, it is the principle whereby the union does not take action (except in the areas that fall within its exclusive competence) unless the potential action would be more effective than action taken at a national, regional, or local level. This principle is closely bound up with the principles of proportionality and necessity, which require that any action by the union not go beyond what is necessary to achieve the objectives of the treaty. See the definition of subsidiarity at $<$ http:/ / europa.eu/scadplus/glossary/subsidiarity_en.htm>.

28 See, for example, Philippe Sands \& Pierre Klein, Bowett's: Law of International Institutions (6th ed., Sweet \& Maxwell 2009); Jan Klabbers, An Introduction to International Institutional Law (Cambridge U. Press 2007); Henry G. Schermers \& Niels M. Blokker, International Institutional Law: Unity within Diversity (4th ed., Martinus Nijhoff 2003).

29 Daniel D. Bradlow, International Law and the Operations of the IFIs, in International Financial Institutions and International Law 1 (Daniel D. Bradlow \& David B. Hunter ed., Kluwer Law International 2010).

30 See, generally, Ian Brownlie, Principles of Public International Law (7th ed., Oxford U. Press 2008). 
legal status. Thus, the principle of national sovereignty imposes some constraint on the demands that an IFI can place on a particular member state and should help each member state preserve as much independence and policy space as is practicable in its relation with each IFI and consistent with the demands of overall effective global financial governance.

\section{Nondiscrimination}

The principle of nondiscrimination applies to both the member states of the IFIs and all those nonstate actors with which the IFIs interact or which are directly affected by their operations. The principle of nondiscrimination means that all similarly situated states and nonstate actors should receive similar treatment in their dealings with the IFIs and that those who are differently situated should receive differential treatment that reflects the differences in their situations. The key question thus becomes what standards can be used for ensuring that all stakeholders receive treatment that is fair and reasonable.

Although the IFIs should base their treatment of all states on the same principles, they should apply these principles in a way that is responsive to the similarities and differences in the situations of each member state and of the affected nonstate actors.

Recognition should be given to the fact that weaker and poorer states are significantly different in capacities from rich and powerful nations. One way of implementing this standard could be to apply the general principle of special and differential treatment that is applicable in a number of international legal contexts, for example, in international environment and international trade law, to international financial governance. In the IFI governance context, this principle means that special attention is paid to ensuring that weak and poor countries are able to enjoy a meaningful level of participation in international financial decision-making structures, even when their participation is based on principles such as weighted voting. For example, in cases where it is not possible to offer states a full seat at the decision-making table, ${ }^{31}$ one alternative could be that the organization create a mechanism through which these states and their citizens can raise concerns in connection with any decisions that adversely affect them and that they do not believe are receiving adequate attention at the relevant decision-making level in the IFI.

The relevant principles applicable to how IFIs should treat natural persons are derived largely from customary international law. This means that they should be derived from the Universal Declaration of Human Rights, which is now considered to be part of customary international law. ${ }^{32}$ Pursuant to

31 For example, boards of executive directors at the IFIs would become too large and unwieldy if all poor and weak member states were full participants in the boards' deliberations that directly affect them.

32 Universal Declaration of Human Rights, GA Res. 217(III), UN GAOR, 3d Sess., Supp. No. 13, UN Doc. A/ 810 (1948); Report of the Special Representative of the Secretary-General on the Issue of Human Rights and Transnational Corporations and Other Business 
this document, individuals, at a minimum, are entitled to expect that the IFIs respect and protect their social, economic, and cultural rights, such as rights to housing, health care, education, jobs, and social security. The IFIs should also ensure that member states' operations do not de facto undermine respect for or protection of their civil and political rights, such as rights to freedom of speech and association. ${ }^{33}$

The situation of juridical persons is more complex because judicial persons are not clearly covered by the Universal Declaration of Human Rights. However, the treatment of foreign juridical persons is covered by the customary international law on state responsibility.

\section{State Responsibility}

Pursuant to the principles applicable to state responsibility for treatment of foreigners located in the sovereign's home territory, ${ }^{34}$ states have an obligation to provide foreign legal persons who are present in the state with fair and equitable treatment. This means that foreign entities should receive treatment that conforms to certain minimum standards, a term not clearly defined in international law, but that at least must be comparable to the treatment of similarly situated domestic institutions. This principle does not necessarily mean that foreign entities should receive the same treatment received by domestic institutions that, because of the particular roles they play in the domestic political economy, have different relations to the state and the market than the foreign entities.

\section{International Environmental Law}

The principles derived from international environmental law ${ }^{35}$ impose on financial regulators an obligation to insist that financial institutions fully understand the environmental and social impacts of their policies and procedures and of their individual transactions.

The principle of respect for applicable international law, therefore, establishes a third test for good governance, namely, to what extent the governance arrangements of the IFIs promote respect for national sovereignty,

Enterprises, paragraph 38, UN Doc. A/HRC / 4 / 35 (2007); also, see, generally, Hurst Hannum, The UDHR in National and International Law, 3(2) Health and Human Rights 144 (1998).

33 For an overview of the World Bank's approach to human rights, see Robert Danino, Legal Opinion on Human Rights and the Work of the World Bank (Jan. 27, 2006), available at <http:/ / www.ifiwatchnet.org/sites/ifiwatchnet.org/files/DaninoLegalOpinion0106.pd>; Siobhán McInerney-Lankford, International Financial Institutions and Human Rights, in International Financial Institutions and International Law 239 (Daniel D. Bradlow \& David B. Hunter ed., Kluwer Law International 2010).

34 See, generally, GA Res. 62/61, UN GAOR, 61st Sess., UN Doc. A/RES/62/61 (Jan. 8, 2008); Report of the International Law Commission on the Work of Its Fifty-Third Session, UN GAOR, 56th Sess., at 43, Supp. No. 10, UN Doc. A/56/10 (2001).

35 See, generally, David Hunter, James Salzman, \& Durwood Zaelke, International Environmental Law and Policy (Foundation Press 2006). 
the environment, and the rights of all natural and legal stakeholders in the international financial system.

\section{Coordinated Specialization}

The principle of coordinated specialization acknowledges that, even though development is holistic and all aspects of international governance are interconnected, IFIs cannot function efficiently without a limited mandate and without the officials in these institutions having the requisite specialist knowledge to implement these mandates. Thus, the principle of coordinated specialization has two requirements in regard to the governance of the IFIs. First, the IFIs' mandates must be clearly defined and limited to their areas of expertise, while not being insensitive to how their specialization fits into a holistic vision of development. Second, the IFIs cannot ignore the fact that other international organizations have expertise in and responsibility for other aspects of development. Consequently, to ensure that all these organizations help their member states implement a holistic vision of development, IFIs need to ensure some form of coordination between themselves and other international organizations. An effective mechanism for ensuring such coordination must be transparent and predictable. It may also need some dispute-settlement mechanism.

In this respect, it is important to keep in mind that the IFIs are not free actors. In some cases, they are subject to receiving "direction" from other intergovernmental entities in which their member states are active. For example, the IMF, together with the World Bank Group and the FSB, is subject to "guidance" from the Group of Twenty (G20). Previously the IMF and the World Bank would receive such "guidance" from the G7.

This principle, therefore, establishes a fourth standard for measuring the adequacy of the IFIs' governance arrangements: the extent to which the IFIs coordinate their policies and operations with other relevant international institutions, each of which has its own limited mandate. At a minimum, this principle should ensure that the IFIs offer other international institutions with relevant areas of expertise a meaningful and timely opportunity to raise their concerns with them. It should also offer both the IFIs and all other relevant international organizations a mechanism for resolving tensions between them.

\section{Good Administrative Practice}

The basic principles of good administrative practice in global governance are the same as those applicable to any public institution: ${ }^{36}$ transparency, predictability, participation, accountability, and clear and predictable rule making. In the case of IFIs, these principles have the following meanings:

36 See, generally, Benedict Kingsbury, Nico Krisch, \& Richard B. Stewart, The Emergence of Global Administrative Law, 68 Law \& Contemp. Probs. 15 (2005), and the materials available on the Institute for International Law and Justice website at <http:/ /iilj.org/publications $>$. 
- Transparency: This term refers to the degree to which an IFI discloses information about its operational policies and procedures, operations, and decisions. ${ }^{37}$

- Predictability: IFIs should conduct their operations in a manner that is sufficiently open so that their procedures, decisions, and actions are predictable and understandable to all stakeholders. An aspect of predictability is that decisions should be made in a timely manner.

- Participation: Mechanisms exist for allowing all stakeholders to participate in the decisions of the IFIs that directly affect them. Important factors to consider are both the extent to which member states are able to express their views and have their votes factored into the decisions of the IFIs and the extent to which nonstate actors can participate in those operational and policy decisions that affect them..$^{38}$

- Accountability: Mechanisms are available to both member states and nonstate actors to hold the IFIs accountable for their actions. ${ }^{39}$ These mechanisms include the channels through which member states can raise their concerns to the highest levels of the institution and the means that nonstate actors can use to have claims that they have been harmed by the actions and decisions of the IFIs heard by the institution. These claims can arise from the contractual relations between these actors and the IFIs as well as from noncontractual claims.

- Clear and predictable rule making: IFIs follow certain procedures in formulating and adopting their operational policies and procedures. Best practice in IFI rule making means that the IFIs provide all stakeholders who have an interest in a proposed policy with an opportunity to comment on the proposed policy, to submit comments on it, and to receive feedback on their comments and submissions. Ideally, the procedures to follow in developing these policies and procedures should be based on clear and predictable rules and should not be ad hoc. ${ }^{40}$

Thus, the final standard against which the IFI governance reforms can be measured is the extent to which they comply with the five principles of good administrative practice stated above.

\section{Summary of the Standards for Evaluating the Governance of the MDBs}

Based on the five principles, following are questions that can be used for assessing the adequacy of the IFIs' governance arrangements:

38 See, for example, Hunter, supra note 24.

39 See Bissell \& Nanwani, supra note 19; Bradlow, supra note 19.

40 See Hunter, supra note 24. 
- Are the governance arrangements based on a holistic understanding of development?

- Are the management arrangements sufficiently flexible to deal with the full range of demands that the IFIs can expect from their diverse collection of stakeholders?

- Do the mechanisms for IFI governance implement and comply with all applicable international law standards, including respect for national sovereignty, the rights of all natural and legal persons, and responsible environmental law practices?

- Do the decision-making procedures in the IFIs provide adequate and meaningful opportunities for coordination with other international institutions with relevant expertise?

- Do IFI governance arrangements comply with the principles of good administrative practice, namely, transparency, predictability, participation, accountability, and clear and predictable rule making?

\section{An Assessment of the IFI Governance Reforms against the Principles of Good Governance}

This section evaluates the extent to which the reforms that have been undertaken in the governance of the IFIs conform to the principles of good governance set out above.

\section{Approach to Holistic Development}

The MDBs have substantially expanded their view of development over the past twenty years. They all recognize that development is not purely an economic process and that it involves social, cultural, political, and environmental aspects. This recognition is reflected, for example, in the safeguard policies of the IBRD and IDA, the performance standards of the IFC, and the comparable social, poverty, gender, and environmental policies at the other MDBs. In addition, the MDBs recognize that political factors are an integral part of the development process, as evidenced by their work in postconflict states and on governance issues and in their statements on such sensitive development issues as gender and indigenous people. However, the IMF, although not denying that development involves more than purely economic matters, has not explicitly incorporated a more holistic vision of development into its operations. This is in part a reflection of its specific monetary and macroeconomic focus. It may also be due, in part, to the fact that the IMF lacks the publicly available operational policies in which the MDBs tend to express their visions of specific aspects of the development process.

Despite the MDBs' impressive efforts in regard to this principle of good governance, one aspect of their approach to development is deficient. They have been slow to link their operational policies and procedures explicitly to 
applicable international legal treaties and conventions and to the declarations, standards, and norms developed in other international organizations and forums. This can be seen, for example, in the policies on involuntary resettlement and indigenous people at the World Bank and the regional MDBs, which are silent about the applicable human rights conventions, declarations, and norms and do not discuss how they should be applied in their operations. This deficiency in the policies of the MDBs, particularly in regard to human rights, may be related to the political prohibitions in their articles, to the fact that the MDBs are not signatories to the relevant international legal instruments, and to the fact that often the applicable standards provide limited guidance on how they should be implemented in dealing with such complex issues as the appropriate standard of compensation in cases of involuntary resettlement or the nature of consent required from indigenous people. Nevertheless, it is striking that the MDBs' policies do not explicitly reference either the applicable international legal standards or the applicable decisions, declarations, or other legal instruments of those institutions and bodies that have the expertise and the mandate to develop the standards and norms in these areas that are outside the scope of the MDBs' assigned areas of expertise. In this sense, the MDBs' implementation of a holistic vision of development is linked to their performance under the coordinated specialization criteria.

\section{Flexible Management}

Although the IFIs have often worked together in specific projects or programs in a country, their interactions have grown more intense over the past twenty years. As a result, they are making greater efforts to ensure better coordination between their operations within specific member states. For example, the MDBs now work to ensure cross-debarments for contractors found to be involved in fraudulent and corrupt practices. ${ }^{41}$ In addition, the independent accountability mechanisms of these institutions have begun to cooperate in joint investigations of projects for which they have received requests for investigations. ${ }^{42}$

The IFIs have enhanced their ability to respond flexibly to developments in their member states by increasing the voice and vote of underrepresented member states in their governance. For example, the World Bank, by increasing the share of the total votes of their developing- and emerging-market member states and by agreeing to a third African chair on its Board of Executive Directors, has enhanced the ability of at least some of these countries to have their voices heard in its decision-making process. In theory, these changes should result in the World Bank being more responsive to the needs and concerns of these countries.

41 See Stephen S. Zimmerman \& Frank A. Fariello, Jr., Coordinating the Fight against Fraud and Corruption: Agreement on Cross-Debarment among Multilateral Development Banks in this volume.

42 For example, the independent review mechanism of the African Development Bank and the World Bank Inspection Panel conducted a joint investigation of the Bujagali Dam Project in Uganda in 2007. 
In addition, the World Bank, with the encouragement of the Development Committee, has initiated a number of organizational reforms designed to enhance its responsiveness to the needs of its member states. ${ }^{43}$ It is actively working to improve the diversity of its workforce so that it is more representative of its full membership. The Bank is also actively working to devolve more management authority from its headquarters to its field staff, which is expected to grow as a portion of the total staff. This effort has been slowed down because of budgetary constraints and the complexities of this change. Finally, and more controversially, the Bank is working to make the formulation of its country assistance strategies a more participatory process that is more responsive to the development priorities of its member states. Some external observers of the Bank are concerned that this effort is intended more to weaken the Bank's current operational policies and standards than to enhance each member state's influence in the Bank's assistance strategy for that country.

These developments could result in a more responsive Bank and in more effective allocations of responsibilities between the World Bank and the other IFIs working in a particular country or region. This in turn would suggest greater compliance with the principle of flexible management. However, these reforms are relatively new, and it is too soon to predict how successful they will be.

\section{Respect for Applicable International Law}

It is clear that all the IFIs respect and work to comply fully with the requirements of their constituent treaties and with the customary international law and general principles of law applicable to them as international organizations. However, it is also clear that it is easier for the IFIs to enunciate these principles than to apply them in the day-to-day management of their operations and in their governance.

In this regard, it is particularly noteworthy how few of the MDBs' operational policies mention relevant international legal principles or explain how management and staff are expected to ensure that operations comply with applicable international law. To some extent, this can be explained by the fact that the applicable international legal principles, standards, and norms are not easy to implement, particularly within the contexts of complex development projects. However, the MDBs cannot avoid dealing with the issues addressed by these international legal principles in their operations, particularly those that raise safeguard issues ${ }^{44}$ Consequently, the fact that there is no reference to these principles, standards, and norms in their policies means, in effect, that

43 See Development Committee, Enhancing Voice and Participation of Developing and Transitional Countries in the World Bank Group: Update and Proposal for Discussion, paragraphs 26-27(a-c), DC2009-0011 (Sep. 29, 2009), available at <http:/ / siteresources.worldbank.org/ DEVCOMMINT/Documentation/22335196/DC2009-0011\%28E\%29Voice.pdf>.

44 World Bank, Safeguard Policies, available at <http://go.worldbank.org/WTA1ODE7T0>; International Finance Corporation, Performance Standards, available at <http:/ / www.ifc. org/ifcext/sustainability.nsf / Content/PerformanceStandards>. 
the MDBs are leaving to their staff and management the responsibility of deciding whether or not to utilize applicable legal principles in their implementation of MDB policies and how to interpret these principles when they do use them. Staff decisions in regard to the applicability and the interpretation of these principles may then be reviewed by the independent accountability mechanisms during their review of the complaints that they receive and the investigations that they conduct of staff and management compliance with the applicable policies, in particular MDB-funded operations.

The decisions of the MDB staff and management and the reports of the independent accountability mechanisms, therefore, amount to precedents of how various international actors are determining the applicability and the interpretation of particular principles, norms, and standards of international law in specific cases. Thus, the MDBs are helping to make the international law in regard to complex issues such as the rights of indigenous people, involuntarily resettled people, treatment of physical cultural property, women in development, and environmental issues such as impact assessments, responsibilities to mitigate adverse impacts, and the nonnavigable uses of international waterways.

Unfortunately, the MDBs appear reluctant to accept the concept that they are de facto establishing precedents on important legal issues that can influence the evolution of these legal principles. As a result, they have not accepted the responsibilities that go with performing law-making functions and so are not effectively meeting their obligations in terms of transparency, participation, and reasoned decision making in this regard. Thus, the MDBs cannot be viewed as being fully compliant with this principle of good governance.

\section{Coordinated Specialization}

The issue of IFIs' relationships with other international organizations has become more important because the scope of their missions has expanded so dramatically. ${ }^{45}$ As a result, IFIs are now undertaking work that involves the specialized competence of other international organizations. ${ }^{46}$ For example, the World Bank funds public health projects that overlap with the expertise and responsibility of the World Health Organization; it funds agricultural projects that may "trespass" into the jurisdiction of the Food and Agricultural Organization or the International Fund for Agricultural Development. However, although they may do so on an ad hoc basis, IFIs are not formally obligated to consult with other international organizations or to ensure that there is effective coordination among them. Given this situation, it is noteworthy

Claudio Grossman \& Daniel Bradlow, Limited Mandates and Intertwined Problems: A New Challenge for the World Bank and the IMF, 17(3) H. Rig. Quar. 411, 412 (Aug. 1995) (also available at <http:// papers.ssrn.com/sol3/papers.cfm?abstract_id=1365257>).

46 In this regard, it is important to recall that the World Bank and the IMF are, de jure, specialized agencies of the UN system. Thus, they are expected to report to the UN Economic and Social Council, and their relationships with the United Nations are governed by the terms of their relationship agreement. 
that the Bank is making a concerted effort to coordinate its operations in crises and emergencies with other international organizations. In this regard, the Bank has updated its operational policies so that they acknowledge the leadership role of other international organizations, particularly the United Nations, in certain aspects of this work. ${ }^{47}$

One consequence of this development is that, because IFIs tends to be better resourced than most other international organizations, they are able to more effectively influence their member states' approaches to issues in which they are interested, even when other organizations have expertise in those issues and the mandate to operate in regard to them. Thus the IFIs tend to become de facto, although not de jure, the primary international bodies for dealing with these issues.

Because their role in these issues is not consistent with the division of responsibility inherent in having international organizations with limited mandates, the IFIs have a distorting effect on the overall global governance architecture. In particular, the MDBs' assertion of influence in a particular area tends to undermine the authority and effectiveness of any other international organization with responsibility in that area. In addition, it creates governance challenges for the IFIs because it means that they have assumed responsibilities in regard to issues and activities for which their governance structures were not necessarily designed.

One possible channel for mitigating this distortion could be through the international bodies in which either the IFIs and these other international organizations or their member states are represented. This is particularly applicable to bodies such as the United Nations Economic and Social Council, the International Monetary and Finance Committee, the Development Committee, and the G20. Although these bodies are not unaware of these governance challenges, they have not yet effectively addressed the global governance distortions that result from the IFIs asserting authority over issues that fall within the expertise and mandate of other international organizations.

\section{Good Administrative Practice}

The best way for determining how well the IFIs are complying with this principle of good global governance is to assess their performance in regard to four aspects of good administrative practice.

\section{Transparency}

Over the past 20 years, MDBs have gone from being closed institutions to being probably the most open international organizations. During this time,

47 See OP 2.30-Development Cooperation and Conflict and OP 8.00-Rapid Response to Crises and Emergencies, available at <http:/ / web.worldbank.org/WBSITE/EXTERNAL/ PROJECTS / EXTPOLICIES / EXTOPMANUAL / 0, , menuPK:64701637 pagePK:51628525 piPK:64857279 theSitePK:502184,00.html>. Also see, generally, Towards a New Framework for a Rapid Bank Response to Crises and Emergencies (World Bank Jan. 12, 2007). 
they have developed, amended, and redrafted information-disclosure policies so that today their basic operational assumption is the opposite of what it used to be: today all information is presumed to be disclosable unless there is a good reason not to disclose the information. ${ }^{48}$ The primary exceptions to this operating assumption are categories of information that do not technically belong to the organization or could have market implications for the institution, the member state, or other actors in the transaction. This is particularly an issue in regard to IFI transactions that involve the private sector. As a result, the IFIs are in substantial compliance with this principle of good governance.

\section{Participation}

The MDBs have made an effort to encourage consultations with all affected peoples in their particular operations. Thus, under the safeguard policies of the IBRD and the IDA, the performance standards of the IFC, and the social and environmental policies of other MDBs, the MDBs are all required to consult with indigenous people, those who will feel the impacts of the MDBs' operations, and those who will be adversely affected by these operations. ${ }^{49}$ In addition, as indicated above, the World Bank has made substantial efforts to incorporate, albeit informally, greater public participation into its rulemaking procedures, at least for those rules of greatest interest to nonstate actors. ${ }^{50}$ Given these developments, the IFIs can be deemed to have made significant progress toward meeting the applicable standards for good governance but are not as yet fully compliant with them.

\section{Accountability}

The IFIs have made significant progress in promoting accountability to nonstate stakeholders in their operations. By 2010, all the MDBs had established independent accountability mechanisms that were authorized to investigate claims from nonstate actors that they had been harmed or threatened with harm by the failure of the MDBs to comply with their operational policies and procedures in regard to a particular project. ${ }^{51}$ These mechanisms usually are independent of the management and staff of the MDBs and report directly to the boards of executive directors of these institutions.

The IMF is the only IFI that has not created an independent accountability mechanism. Although the nature of its operations is different from that of the other IFIs, the IMF could establish some form of independent accountability mechanism. ${ }^{52}$ In fact, given that its operations have important impacts on nonstate actors in its member countries and that these impacts are not necessarily well understood by the institution, the creation of such a mechanism

49 See supra note 44.

50 See Hunter, supra note 24.

51 See Bissell \& Nanwani, supra note 19; Bradlow, supra note 19.

52 For one model of such a mechanism for the IMF, see Bradlow, supra note 20. 
could have a positive impact on the IMF and thus improve the quality of its operations. In this regard, it should be noted that the IMF's board of executive directors can introduce such a mechanism on its own authority without any decision by its board of governors or amendment to its articles of agreement.

The IFIs have made less progress in promoting accountability to those member states that use their financial services but are not directly represented on their boards. These states, in principle, can use the executive director representing them on the board of the particular IFI to raise issues of concern to the board. However, the current constituency system of representation at the board level makes this difficult in practice. The reason is that the executive director may not believe it is an opportune time to raise a claim to his or her board colleagues; there are only limited ways for a frustrated state to hold the executive director accountable for this decision. In this regard, the recent efforts of the World Bank and the IMF to hold their boards more accountable for their performance is a positive development that has the potential to result in more accountable IFIs.

\section{Clear and Predictable Rule Making}

Over the past twenty years, the World Bank Group has evolved an informal practice of participatory rule making. The practice has not yet been formalized into a "policy on policies," but it has evolved from the practice the Bank has followed in connection with important Bank Group policies. Thus, the practice of consulting interested stakeholders, providing opportunities for interested parties to submit comments on draft policies, and responding to these comments was a prominent feature of the development of the indigenous people's policy and the information-disclosure policy in the IBRD and the IDA and of the review of the performance standards in the IFC. This practice has also been used in the reviews of the independent accountability mechanisms of the IBRD and IDA, the European Bank for Reconstruction and Development, the Inter-American Development Bank, the Asian Development Bank, and the African Development Bank. A version of it was followed by the IMF in its review of its conditionality policy. However, this practice remains informal and at the discretion of an IFI. It is not yet consistent practice, and the process followed in each policy review is a matter for discussion and negotiation. Therefore, while the IFIs have made substantial progress toward meeting this principle of good governance, they are not yet fully compliant with it.

\section{Conclusion}

This chapter has set out a framework for assessing efforts to reform the governance of the IFIs. Based on this framework, it is clear that, while the recent reform efforts, despite the setback in the selection of the current IMF managing director, have the potential to produce substantial changes in the operations and governance of the IFIs, they do not fully comply with the principles of good governance. However, the international community, in light of the 
problems in Europe, the uncertain state of the global economy, and the ongoing shifts in global power, seems to have exhausted its interest in reforming IFI governance. Consequently, there is little reason to expect the additional reforms that are required for full compliance to be undertaken in the short run. Nevertheless, it is to be hoped that in the medium term the shift in the balance of global political and economic power will create the conditions for another round of significant IFI governance reforms. 